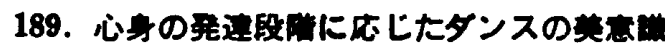

京都数育大学○五十篮英子 武異川女子大学 河 井 冨美惠 桃山学院大学林说子

研究目的人間の特性とする思考，情緒の発逞は，身

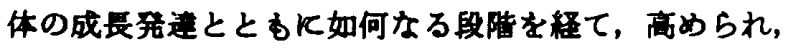
深められていくか，又それが芸術などの対象物に対して の美意䋨として，現れ方の推移をみるため，その1埌と して幼児期の美意嵁を周査し，特に舞踊における身体活

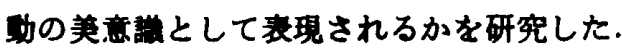

研方方法 対象…大岅，奈良県下の幼児2才6ヶ月〜 6 才 7 ケ月50名.

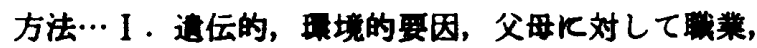

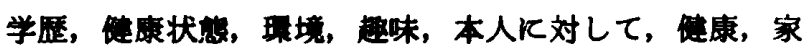

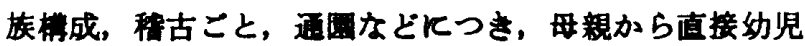

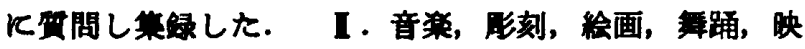
画，テレビ，体操，自然現鮽等に対し，メロディー，音 色，リズム，形，色，功き，惑觉，内容の分野について 美の捉え方を集計した．【．【の项目を更に言語，功 き，表情，模做，再現の分可にわけ，表現の手段として 整計した。

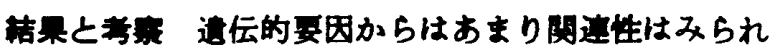
なかつたか，環境的要因から，都市や数育程度の高い家 庭に於て，音桨，舞踊など芸街に対する成心度が高い。

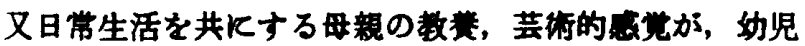
にも影重され，その美意諳る年令と共に向上する結果を

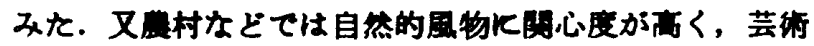

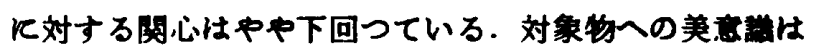
主として，形，色て捉えられ洋㰠，野き，音，飞移行し ている。そしてその\%は3，4才児から，5，6才児にな ると従つて高い数值を示している.これらはフライアン ・グッドイナフ等多くの心理学者の实证と一致してい

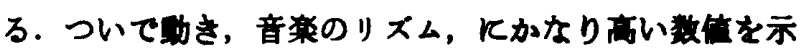
していろ. 今迄助きとしている内容はバレェなどのきり きりときれいKまわる. 手あしがやわらかく娌く，とい つたもので，3，4才児からこのよろな㒸眼点は曼近の幼 児の美意浀の一傾向とみられる. 表現の手段について， 言語表現から（きれいだ，わあすこいという形容浯，忽

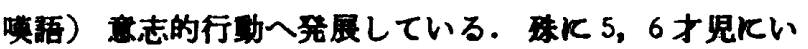

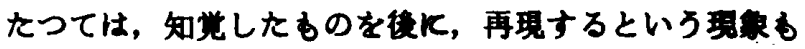
員著に出ている。これらの結果から奻児の美意期は心身

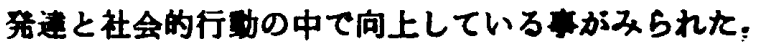

190. 年呞におけるイメージに成する研究 大阪数青大学○頭川 昭子

" 柏原储三

I. 研究目的 視觉刺敞の受けとめ方を四つの角度の 見えるるのの形を表現する. (2)見えるすのの感じを表現

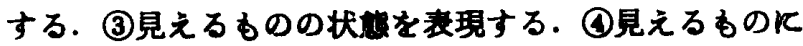
上つて自分の文持を表渭する．K分けそれらの課题から どのような直助のイメージをえがき，どのように変化牽 展させて表現するのかをみるるのである。

I. 研究方法 昭和45年6月〜7月Kかけて，さつき 保青国国児14名，本巣がンス部員 7 名を対象Kして，(1)

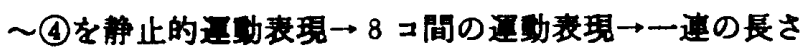
の荤的表現を行なわせ，フィルムとビデオューダに郡録 した.

\section{I. 洁果と新腺}

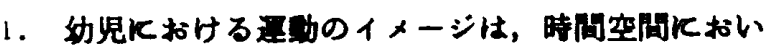
て分化されているが，目分と他との閶係は分化されてい

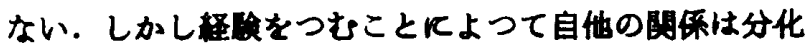
され意味の建いを教できることは大学生ダンス部買に おいてみられる。

2. 静止的迋功表現から一速の長さの迋功表現への変

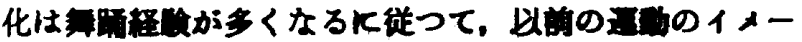
ジはより鲜明に瑟存している。（因表む明）

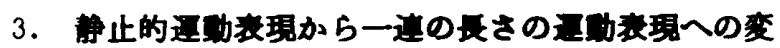

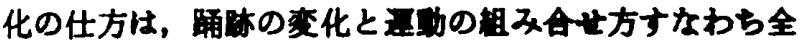

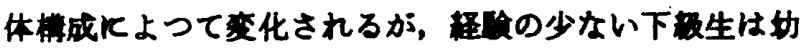
坚と同じ単一正的て踊跤の化を行ない, A BCD, A

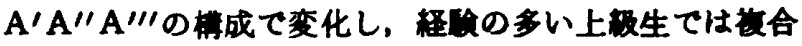

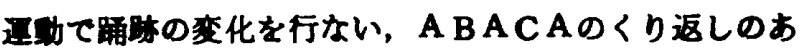

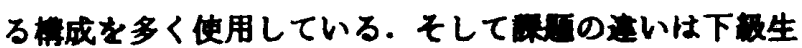

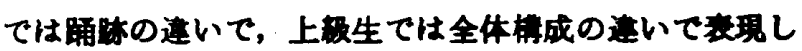
ているのがみられた.

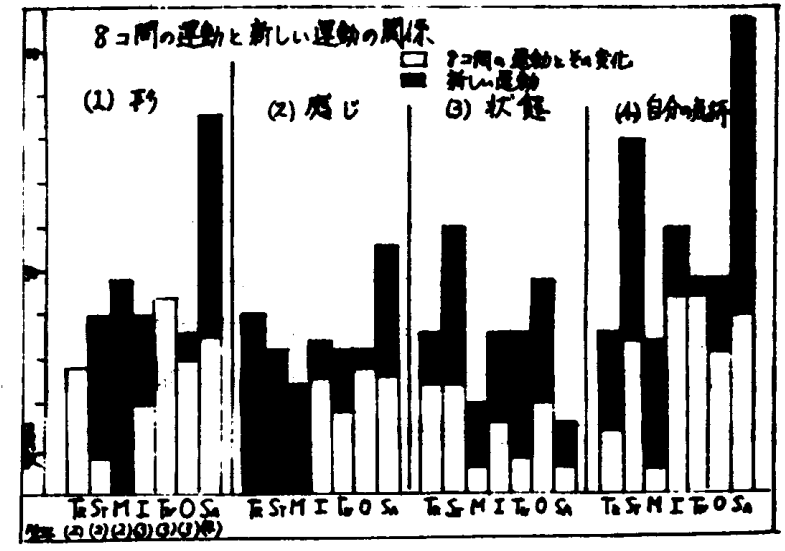

